\title{
The future of medical careers
}

\section{How can we ensure that medical workforce supply matches population health need?}

\section{T} he medical workforce in Australia is undergoing substantial changes. Oversupply of domestic medical graduates, coupled with growth in international entrants, has led to increased competition for internships and prevocational training positions. ${ }^{1,2}$ In coming years, more applicants will vie for vocational training positions in their preferred fields and many doctors may be disappointed in their eventual career pathways. ${ }^{3}$ Such challenges should have been foreseen when the new medical schools were established; however, the health system has reacted slowly.

The relative freedom historically enjoyed by doctors in choosing their vocational pathways has resulted in imbalances across geographic regions and between specialties. There is strong competition for those regarded as desirable (eg, high-status and highly paid specialties such as surgery ${ }^{4}$ ), while others continue to experience relatively low interest. Recent modelling suggests that the generalist specialties, including general medicine and psychiatry, as well as general practice, will continue to experience shortages. ${ }^{5}$

Should we and can we manage medical careers in a more proactive fashion, so that young doctors are ushered into geographic areas of need and are encouraged to specialise in clinical areas that will effectively meet population health needs? Should the regulation of practice location be changed, and what is the feasibility of changing the allocation of vocational training places across specialties? Can medical careers be made more flexible and generalist in their nature?

Governments and employers wish to shape medical careers in some of these ways. ${ }^{6}$ However, a recent review found little evidence that this can be done. ${ }^{7}$ Medical career choices are a complex mix of individual aptitudes, preferences and characteristics; the structure of, and experiences during, undergraduate and postgraduate education; and the expected characteristics of different medical careers and jobs. The literature is not clear as to which of these factors policymakers should focus on. Studies have considered the potential role of clinical supervision and mentoring ${ }^{8,9}$ and career advice. ${ }^{10}$ Providing information on the availability of specialty jobs may also be important. ${ }^{11}$ Interventions may be most effective in early postgraduate years, when doctors generally make their career decisions. ${ }^{12}$ Doctors from a rural background are more likely to choose rural practice, but there is much less evidence on the role of incentives to encourage practice and retention in rural areas or areas of socioeconomic disadvantage. ${ }^{13}$ There is evidence that the characteristics of specialties play a role, including flexibility of working hours and earnings; however, these may be more difficult to change. ${ }^{14} \mathrm{To}$ improve the evidence base, we need better study designs and more capacity to undertake health workforce research. Although the Productivity Commission recommended more research almost a decade ago, little has changed. ${ }^{15}$

Longer term solutions require us to consider the economics of the medical labour market. The 20-year boom-bust cycles of the health workforce involve relatively rapid expansions and contractions of supply and demand that affect the health care system and patients. ${ }^{16,17}$ However, governments have ignored the basic economics of demand and supply and have failed to manage these fluctuations strategically. Decisions to increase medical school places to meet increases in demand did not taken into account expected costs or benefits to the health system of employing more doctors, and failed to consider more potentially cost-effective doi: 10.5694/mjal3.00063 ways of improving population health, such as changes in skill mix.

Although competition may help to keep wages down and quality high, oversupply can also lead to unemployment. Market imperfections and failures in health care mean that costs will not necessarily fall and that quality will not necessarily increase when supply increases. For example, bargaining agreements in public hospitals and fixed Medicare fees mean that doctors' earnings lack flexibility. Increasing the number of doctors does not necessarily improve population health, as issues of overdiagnosis and overtreatment are becoming more prominent ${ }^{18}$ and suggest that we are already at or beyond the flat of the curve of effective medical care.

An evidence-based approach to managing medical careers to improve population health is a laudable goal, but there is insufficient evidence on how best to do this. Government interventions to manage the medical workforce have been largely ineffective, but this does not mean that market forces should rule without government intervention. As purchasers of medical labour, governments should focus more on strengthening relative price signals and improving flexibility and information in health care labour markets to nudge the market in the desired direction.

A number of new interventions may be appropriate. First, more national information about career options, vacancies and employment rates in specific specialties and specialty training programs could be provided, so that choices can be more informed, realistic and 
unbiased. In such a competitive labour market, doctors will also want to be treated fairly and based on merit. ${ }^{3}$ A second option is to begin to think seriously about altering the structure of medical training to promote flexibility and generalism. ${ }^{19,20}$ Long periods of training and increasing subspecialism foster inflexibility such that, in times of shortage or surplus, doctors are unable to change specialties or unwilling to move to geographic areas in need. Is the nature and structure of medical training inhibiting the pursuit of improved population health? Health Workforce Australia has been abolished at a crucial time when new policies need to be developed. Maintaining the momentum is essential to produce a medical workforce that can continue to improve the population's health.

Acknowledgements: We thank the National Health and Medical Research Council (NHMRC) Centre for Research Excellence in Medical Workforce Dynamics, which funds the Medicine in Australia: Balancing Employment and Life longitudinal survey of doctors. Anthony Scott receives funding from an NHMRC Principal Research Fellowship. The Evidence Check Review ${ }^{7}$ was brokered by the Sax Institute on behalf of the New South Wales Ministry of Health.

Competing interests: No relevant disclosures.

Provenance: Not commissioned; externally peer reviewed.

1 Department of Health and Ageing. Medical Training Review Panel: sixteenth report. Canberra: Commonwealth of Australia, 2013. http://www.health.gov. au/internet/publications/publishing.nsf/Content/work-pubs-mtrp-16-toc (accessed Apr 2014).

2 Hawthorne L. International medical migration: what is the future for Australia? MJA Open 2012; 1 Suppl 3: 18-21. (accessed Apr 2014).

3 Keva D, Lander FJ. Emerging inequality and potential unconstitutionality - the case for reform of the intern priority system. Med J Aust 2013; 198: 334-337.

4 Creed PA, Searle J, Rogers ME. Medical specialty prestige and lifestyle preferences for medical students. Soc Sci Med 2010; 71: 1084-1088.

5 Health Workforce Australia. Health Workforce 2025. Medical specialties. Volume 3. Adelaide: Health Workforce Australia, 2012. https://www.hwa.gov. au/sites/uploads/HW2025_V3_FinalReport20121109.pdf (accessed Apr 2014)

6 Health Workforce Australia. National Medical Training Advisory Network. Discussion paper. Adelaide: Health Workforce Australia, 2013. https://www. hwa.gov.au/sites/uploads/20130222_FINAL_HWA_NMTAN_discussion_ paper.pdf (accessed Apr 2014).
7 Scott A, Joyce C, Cheng T, Wang W. Medical career path decision making. A rapid review. Sydney: Sax Institute, 2013. https://www.saxinstitute.org.au/ wp-content/uploads/REPORT_Medical-career-path.pdf (accessed Apr 2014).

8 Stagg P, Prideaux D, Greenhill J, Sweet L. Are medical students influenced by preceptors in making career choices, and if so how? A systematic review. Rural Remote Health 2012; 12: 1832.

9 Buddeberg-Fischer B, Herta KD. Formal mentoring programmes for medical students and doctors - a review of the Medline literature. Med Teach 2006; 28: 248-257.

10 Davison I, Burke S, Bullock A, et al. Evaluation of a pilot careers advice service for junior doctors. Med Teach 2006; 28: 561-563.

11 Harris JE, González López-Valcárcel B, Ortún V, Barber P. Specialty choice in times of economic crisis: a cross-sectional survey of Spanish medical students. BMJ Open 2013; 3: e002051.

12 Medical Deans of Australia and New Zealand. Medical Schools Outcomes Database. 2011 PGY1 National Data Report. Sydney: Medical Deans Australia and New Zealand, 2012. http://www.msod.org.au/images/publications/ data-reports/2011\%20PGY1\%20report.pdf (accessed Apr 2014).

13 Jones M, Humphreys JS, McGrail MR. Why does a rural background make medical students more likely to intend to work in rural areas and how consistent is the effect? A study of the rural background effect. Aust J Rural Health 2012; 20: 29-34.

14 Sivey P, Scott A, Witt J, et al. Junior doctors' preferences for specialty choice. J Health Econ 2012; 31: 813-823.

15 Productivity Commission. Australia's health workforce. Canberra: Productivity Commission, 2005. http://www.pc.gov.au/projects/study/ health-workforce/docs/report (accessed Apr 2014).

16 Scott A, Sivey P, Joyce C, et al. Alternative approaches to health workforce planning. Final report. April 2011. Adelaide: Health Workforce Australia, 2012. https://www.hwa.gov.au/sites/uploads/Alternative\%20Approaches $\% 20$ to\%20Health\%20Workforce\%2OPlanning.pdf (accessed Apr 2014).

17 Murray RB. Do available predictions of future medical workforce requirements provide a sensible basis for planning? No. Med J Aust 2012; 197: 267.

18 Elshaug AG, Watt AM, Mundy L, Willis CD. Over 150 potentially low-value health care practices: an Australian study. Med J Aust 2012; 197: 556-560.

19 Independent Inquiry into Modernising Medical Careers. Aspiring to excellence. Findings and recommendations. London: MMC Inquiry, 2008. http://www. medschools.ac.uk/AboutUs/Projects/Documents/Final\%20MMC\%20 Inquiry\%20Jan2008.pdf (accessed Apr 2014).]

20 Shape of Training. Securing the future of excellent patient care. Final report of the independent review led by Professor David Greenaway. London: Shape of Training, General Medical Council, 2013. http://www.shapeoftraining. co.uk/static/documents/content/Shape_of_training_FINAL_Report. pdf_53977887.pdf (accessed Apr 2014). 